\section{蕞ACFE \\ Indonesia Chapter \#111}

Asia Pacific Fraud Journal

E-ISSN: 2502-695X, ISSN: 2502-8731

Volume 5, Nomor 2 (July-December) 2020

http://apfjournal.or.id/index.php/apf

\title{
THE RELATION OF CORRUPTION POTENTIAL PERCEPTION WITH BUSINESS INTEGRATION, PUBLIC INTEGRATION, AND LOCAL INTEGRATION SYSTEM (FROM CORRUPTION PERCEPTION SURVEY ANALYSIS)
}

\author{
${ }^{\otimes 1}$ Posma Sariguna Johnson Kennedy, ${ }^{2}$ Santi Lina \\ ${ }^{1}$ Universitas Kristen Indonesia, Jakarta, Indonesia \\ ${ }^{2}$ Universitas Kristen Maranatha, Bandung, Indonesia
}

\author{
ARTICLE INFORMATION \\ Article History: \\ Received June 19, 2019 \\ Revised July 8, 2019 \\ Accepted Dec 26, 2020
}

DOI:

10.21532/apfjournal.v5i2.160

\begin{abstract}
ABTRACT
Potential of corruption is a condition that allows corruption criminal to occur. This paper aims to see whether perceptions of potential corruption have a relationship with business integrity, public integrity, and local integrity systems. The research method used is analysis by looking at the relationship between variables using Rank Spearman test. The results indicate that perceptions of potential corruption have relationship with local integration systems, local integration systems have relationship with the perceptions of business integrity, and the perceptions of business integrity have relationship with public integrity. Thus there are findings that, the eradication of corruption can not be initiated from public integrity, but must be initiated by the improvement of a clean system.
\end{abstract}

Keywords: Corruption, Business Integrity Perception, Corruption Potential Perception, Local Integrity System, Public Integrity Perception.

\section{INTRODUCTION}

Corruption is a misuse of authority for the purpose of gaining benefits for personal gain that is very harmful to society and the state. In order to accelerate efforts to prevent and eradicate corruption in Indonesia, the government has issued Regulation of the Peraturan Presiden Republik Indonesia Nomor 55 Tahun 2012 on the National Strategy for Prevention and Combating Corruption (Strategi Nasional Pencegahan dan Pemberantasan Korupsi, or Stranas PPK) in medium-term years 2012-2014 and in long-term years 2012-2025. As a follow up to the formulation of Stranas PPK, Government prepares Anti-Corruption Prevention and Eradication Action which is implemented and evaluated every year. In the action plan of anti-corruption prevention and eradication (Rencana Aksi Pencegahan dan Pemberantasan Korupsi, or Renaksi KDP), The President of Indonesian Republic expressly instructs all levels of government both at local and regional level (Governor and Bupati/ Walikota) to implement the Stranas PPK. In the context of the Stranas PPK, regions have different powers and actions with the national, thereby providing tools for impacting the implementation of the action plan as necessary to measure the risk and effectiveness of the regional Stranas PPK. The eradication and prevention of regional corruption is considered successful if there is an increase in the Indonesian Corruption Perceptions Index and Local-Indonesian Integrity System.

The paper aims to examine whether potential perceptions are related to

Association of Certified Fraud Examiners (ACFE) Indonesia Chapter Page. 221-232 
business integrity, public integrity, and local integrity systems. By measuring this perception of corruption, wanting to prove that corruption is not just a matter of the convenience of business effort, but also distorting local competitiveness, reducing public integrity, and degrading business integrity.

\section{LITERATURE REVIEW AND HYPO- THESIS}

According to Wertheim (1965), there are three main phenomena covered by the term of corruption in Southeast Asian countries: bribery, extortion, and nepotism. Bribery occurs when a government employee receives a reward offered by a person with the intention of influencing him to give special attention to the giver's interests. Extortion is a request for gifts in the execution of public duties, including officials who use public funds they charge for their own benefit or those who are guilty of embezzlement over the price to be paid by the public. Nepotism is the appointment of relatives, friends or political colleagues in public offices regardless of their services or their consequences to public welfare. (BPS, 2012)

Central Bureau of Statistics (Badan Pusat Statistik or BPS), write down the cultural root of corruption, there are:

- Presence of a tradition of giving gifts to government officials. Such actions in Europe or North America can be considered corruption as a form of compliance with obligations by the subjects to their master.

- Family ties and allegiance in eastern societies such as Indonesia are still considered very important. One's duty is to first take notice of the nearest relative, then the breed or ethnic group. In this kind of culture, if there is someone who visits his brother whose officials ask for special treatment is difficult to reject. So there is always a value conflict, that is between cultural norms or formal legal norms.

Economic factors are one of the causes of corruption. It can be explained from the income or salary that is not sufficient. This opinion is not absolutely true, because in Maslow's theory of need, corruption should only be done by people to meet the two most basic needs, and just being done by a mediocre community of survivors. But now corruption is done by the rich and highly educated. (Sulistyantoro, 2004)

Others argue that the lack of salaries and income of civil servants is indeed the most prominent factor in the sense of evenly spreading and widespread corruption in Indonesia. Suggested by Guy J. Pauker (1979) which states: "Although corruption is widespread in Indonesia as means of supplementing excessively low governmental salaries, the resources of the nation are not used primarily for the accumulation of vast private fortunes, but for economic development and some silent, for welfare."

This opinion is reinforced by Schoorl who states that in Indonesia, in the first part of the sixties, the situation is so declining, so for the largest group of salary employees, a month just enough to eat two weeks. It is understandable that in such situations employees are forced to seek additional income, and that many of them earn it by asking for extra money (Hamzah, 1991).

It is also disclosed by the KPK in book of Tambahan Penghasilan Bagi Pegawai Negeri Sipil Daerah (the Supplementary Income Book for Regional Civil Servants, KPK, 2006), that the personnel take home pay is closely related to the performance of the government apparatus. Salary levels that do not meet minimum employee living standards are difficult issues that must be solved. The government apparatus who feels the income he receives is not in accordance with the contribution he/she gives in carrying out his/her main duty will not be able to optimally carry out its main task.

In addition to the low salaries of employees, many other economic aspects are the cause of corruption, including government power coupled with the opportunity factor for government employees to meet their wealth and cronies. Related to economic factors and 
the occurrence of corruption, many argue that poverty is the root cause of corruption. Such statements are not completely true, because there is a lot of corruption committed by Asian and African leaders, and they do not belong to the poor. Thus corruption is not caused by poverty, but on the contrary, poverty is caused by corruption (Pope, 2003).

Corruption behavior can arise from both internal and external factors. Internal factors are caused by weak moral aspects, such as weakness of faith, honesty, shame, attitude or behavioral aspects such as consumptive lifestyle, and social aspects such as family that can encourage someone to behave corruptly. External factors can come from economic aspects such as incomes or inadequate salaries, political aspects such as political instability, political interests, achieving and maintaining power, management and organizational aspects ie lack of accountability and transparency, legal aspects, seen in the poor form of legislation and weakness of law enforcement and social aspect that is environment or society which less support anti corruption behavior. (Siregar, 2017)

Fraud losses include corruption of any degree, mostly taken by men. The average age of most fraud perpetrators is aged $36-45$ years, then performed by the age of 46-55 years. The age shows that fraud actors are in a very productive position and are usually in the top position. Education of the largest perpetrators of fraud in Indonesia is a scholar and above. This raises questions about the process of higher education in Indonesia. The higher education must prioritizes the process of honesty, integrity, and others, rather than higher education that only emphasizes the expertise. (ACFE in Kennedy, 2017).

\section{Corruption Demand Side: Perception of Corruption Potential}

Potential corruption can occur due to five things, namely: high prevalence of corruption, low accountability of public funding, high corruption motivation, widespread corruption-affected sectors, and the effectiveness of anti-corruption programs in the region. The prevalence of corruption is the size of what or how often corruption in the form of bribery and abuse of authority for personal interests occurs at the national or local level, and/or occurs within national or local officials. Public funding accountability is the mechanism of accountability for the use of public funds. How clear is the standard procedure for the allocation of public resources, how common are non-accountable allocations of non-budgeters openly, are there any mechanisms for recruitment of nontransparent public officials, whether there is an internal oversight body auditing public finances, and whether there is a judicial independence that takes action against corrupt officials.

The motivation of corruption is the impetus of a public official conducting a criminal act of corruption. For example, is the practice of preferential treatment taking place, whether the practice of corruption to give excessive political donations, whether corruption creates off budget funds for political parties occurs, corrupt practices to secure government projects occur, corruption practices due to the sale and purchase of influence. Corruptionaffected sector is an assessment of the public sector if it is entangled in corruption cases. Public sector assessed includes the licensing sector, basic services, taxation, procurement, judiciary, trade quotas, police, credit, customs, inspection agencies, military, executives and legislatures. The effectiveness of anti-corruption programs is an assessment of how well the prevention and law enforcement efforts of corrupt officials are decreasing the risk of corruption.

Regions with high corruption perception index indicate that the regions have significant progress in eradicating corruption in their regions. On the contrary, regions that tend to stagnate/decrease their corruption perception index show stagnation / decrease in efforts to eradicate corruption in the regions. 
The Corruption Supply Side: Perceptions of Potential Bribery

The potential for corruption is measured as an approach to the demand side of corruption, vice versa, the potential for bribery should be measured as the supply side approach of corruption. The Potential of a bribery is an assessment of how much the impact of bribery on the practice of fair business principles. Specifically the potential for bribe payments in this survey is identified through how much percentage of business competition is won through the practice of bribery. The potential for bribes is calculated in two ways: calculating the prevalence and the type of bribe, and calculating the cost of bribes.

Assessment of prevalence and types of bribes is done by assessing respondents' perceptions of: bribes, lubricant money, political donations, and inter-private bribes. The distinction of these four types of bribery is based on differences in value gradations and bribery intentions. Highprevalence cities for all four types of bribes have high potential for bribes, whereas low-prevalence cities for these four types of bribes have low bribery potential. The assessment of the potential of subsequent bribes is obtained through the calculation of the average of bribery allocations paid by the company. The city with the largest average allocation of bribes has the highest potential for bribery, otherwise cities with low bribe allocations have a low bribe potential as well. Differences in inter-regional economic capacity result in potential impacts on potential corruption and different bribery potentials. Areas with high corruption potential and high bribery potentials have potentially high economic impact. Conversely, the potential for corruption and the potential for low bribes has the potential for a low economic impact.

\section{Perceptions of Business Integrity}

Business Integrity is an assessment of the corruption prevention infrastructure that has been developed or implemented by employers. Businesses with integrity are perceived to be able to reduce the risk of corruption through strengthening the commitment of the company and by implementing integrity business pillars, such as code ownership, codes of conduct, anti-corruption policies, antiantigratification programs, anti-corruption training and channel whistleblowing system.

Business integrity has a close relationship with potential bribes. Areas with poor business integrity have high potential for bribes. There are five things that the entrepreneur considers to be a graft of corruption. Due to the existence of this, corruption is still happening and repeated. The five things are namely: corruption is not criminally convicted, corruption is not considered an important phenomenon, corruption is not considered a policy priority, corruption is allowed, and corruption is considered a habit. As a form of entrepreneur responsibility in eradicating anti-corruption, entrepreneurs have had prevention designs that are in harmony with the company's integrity system.

The elements of the prevention system include a code of ethics that strictly prohibits the practice of bribery, gratification, grease, conflict of interest; ownership of anti-corruption programs; anticorruption program communication; credible whistleblowing system; effective complaint handling mechanism; and reports of anticorruption programs accessible to the public. In addition, they also identify the necessary preconditions for the business sector to strengthen the company's integrity system. These preconditions are the joint Action against Corruption, the Anti-Corruption Audit Program, the Certification of Business Partners, the Implementation of AntiCorruption Policies, and the AntiCorruption Standard for the Company.

Differences in inter-city economic capacity result in potential impacts of potential corruption and the practice of bribery distorted business competition across different regions of the survey. 
Areas with high corruption potential and high bribery distorted business competition practices have potentially high economic impact. In contrast, the potential for corruption and low bribery distorted business competition practices has the potential for a low economic impact.

\section{Public Integrity}

Public integrity is an assessment of the experience of interaction of entrepreneurs with the practice of bribery in public institutions at the central, vertical, provincial, municipal, or state-owned levels (BUMN). The process of public integrity assessment is complemented by measurement of the suitability of service procedures and service implementation, intensity of reporting of maladministration events, and a person's preference for bribery.

Public integrity has a close relationship with the potential for corruption. Areas with poor public integrity have high potential for corruption. This section is asked about the risks of public integrity violations. The risk assessment of integrity violation is done with two indicators. First, counting the incidents of bribery in each public agency. The higher the incidence of bribery, the public integrity will get worse. Second, calculate the bribery probability which is the ratio between the bribery incident to the total public service interaction. The higher the probability of bribery, the greater the public's integrity will be.

\section{Local Integrity System}

The Local Integrity System is an assessment of expectations, capacity, roles, and quality of governance of key actors in the eradication of corruption in regions that can contribute to the effectiveness of prevention and eradication of corruption in the region. Corruption is considered to occur systemically. So, systemic approach is needed to eradicate corruption. systematic mapping needs to be made to know which pillars are expected to contribute greatly in the effort to eradicate corruption. In addition, it is also necessary to evaluate which pilats have the most role, capacity and governance in combating corruption. The higher the gap between expectations and role-capacity-governance, the weaker the local integrity system. Vice versa, the lower the gap between expectations and role-capacity-governance, the stronger the local integrity system.

\section{METHODS}

The method of research conducted in this study, is descriptive analysis by looking at relationships quantitatively among variables, namely perceptions of potential corruption, business integrity, public integrity, and local integrity systems. The data is taken according to respondent's perception. The testing tool uses non parametric methodology, that is Rank Spearman Test. All data using the result of Corruption Perception Survey conducted by Lembaga Tranparency International Indonesia.

Lembaga Tranparency International Indonesia conducted a Perception of Corruption Survey (2015). The survey aims to map the risk of corruption and assess the effectiveness of anti-corruption programs in the achievement of the Stranas PPK targets. More specifically, the 2015 Corruption Perceptions Survey aims to collect intertemporal and intercity data that can illustrate competitiveness and constraints; potential for corruption and the integrity of public services; potential for bribery and integrity of the business sector, assessment of local integrity systems, and assessment of regional economic performance.

The Corruption Perceptions Survey is conducted in eleven cities in Indonesia with the following considerations: 1) Provinces where the survey city is located have the largest contribution in the national gross domestic product; 2) Contribution of provincial gross domestic product in which the survey city is cumulatively reaches nearly 70 percent of national gross domestic product and 3) Cities are selected to consider the area of dispersion of economic activity in accordance with 
zoning or area methods. That is the western part of Indonesia, central and east.

In accordance with the category selected eleven cities, namely: (1) Pekanbaru, (2) Semarang, (3) Banjarmasin, (4) Pontianak, (5) Makassar, (6) Manado, (7) Medan, (8) Padang, (9) Bandung, (10) Surabaya, and (11) Jakarta Utara.

Respondents to the Corruption Perception Survey 2015 are entrepreneurs. Entrepreneurs who are selected as respondents in this survey are entrepreneurs who have experience interacting with at least one type of public service center, vertical, provincial, municipal, and or State-Owned Enterprises/Regional Owned Enterprises in the last twelve months. The total sample of entrepreneurs involved in the survey was 1,067 entrepreneurs. Companies fall into small categories if they have a workforce of less than or equal to 49 workers, firms fall into the middle category if they have between 50 and 99 workers, and firms fall into the big category if they have a workforce of over 100 workers.

Sampling was done using stratified random sampling. The sample framework of employers used is sourced from the Directory of Industrial Companies 2014 published by the Central Bureau of Statistics. The data collection of the Corruption Perceptions Survey 2015 conducted by Transparency International Indonesia is assisted by the coordinator of the simultaneous survey area in eleven cities in Indonesia from May to June 2015.

\section{RESULT AND DISCUSSION} Perception of Corruption Potential

In a survey of potential corruption reviewed five categories, namely: the prevalence of corruption; public accountability; corruption motivation; the impact of corruption; and the effectiveness of corruption eradication. Potential corruption is rated 0 if it is very corrupt and 100 if it is very clean.

With these categorization are known that the main contributor to the potential corruption score in 2015. The effectiveness of corruption eradication with a score of 56 , public accountability with a score of 56, corruption impact sector with a score of 55, the prevalence of corruption with a score of 53, and the motivation for corruption with a score of 52 .

Based on data, the effectiveness of corruption eradication and public funding accountability has contributed most to the decline in the potential for corruption. The decreasing potential for corruption is also contributed by improved perceptions of corruption-affected sectors, decreasing corruption prevalence, and decreasing corruption motivation.

Data from 2014 can be seen in the following table 1.

In 2015, the City with the highest Corruption Perceptions Index score is Banjarmasin with 68, Surabaya with score 65, and Semarang with 60. Meanwhile, lowest is Bandung with a score of 39, Pekanbaru with a score of 42, and Makassar score 48. It can be seen in the table below.

The region with the highest growth score of corruption perception index is Medan with an increase of 8 points, North Jakarta (Jakarta Utara) with 8 points increase, and Bandung with 7 points increase. Meanwhile, the regions with the

Table 1. Potential Corruption

\begin{tabular}{llccc}
\hline No. & \multicolumn{1}{c}{ Categories and Elements } & 2014 & 2015 & 2016 (expectation) \\
\hline 1. & Prevalence of corruption & 48 & 53 & 58 \\
2. & Financial accountability & 52 & 56 & 61 \\
3. & Corruption motivation & 47 & 52 & 58 \\
4. & Corruption-affected sectors & 50 & 55 & 61 \\
5. & Corruption eradication and prevention & 52 & 56 & 64 \\
\hline
\end{tabular}

Note: Potential corruption is rated 0 if it is very corrupt and 100 if it is very clean. Source: Transparency International (2015) 
Figure 1. Corruption Perceptions Index of 2015

\begin{tabular}{|c|c|c|c|c|c|c|}
\hline Peringkat & Kota & Skor & & Perubahan & Sebelumnya & Akan Datang \\
\hline 1 & Kota Banjarmasin & 68 & & 0 & 68 & 64 \\
\hline 2 & Kota Surabaya & 65 & 6 & 6 & 59 & 70 \\
\hline 3 & Kota Semarang & 60 & 61 & 4 & 56 & 60 \\
\hline 4 & Kota Pontianak & 58 & 5 & 4 & 54 & 58 \\
\hline 5 & Kota Medan & 57 & 58 & 8 & 49 & 63 \\
\hline 6 & Kota Jakarta Utara & 57 & 5 & 8 & 49 & 67 \\
\hline 7 & Kota Manado & 55 & 5 & 4 & 51 & 55 \\
\hline 8 & Kota Padang & 50 & 5 & 2 & 48 & 50 \\
\hline 9 & Kota Makassar & 48 & 4 & 2 & 46 & 48 \\
\hline 10 & Kota Pekanbaru & 42 & 8 & 7 & 35 & 42 \\
\hline 11 & Kota Bandung & 39 & 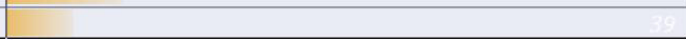 & 7 & 32 & 39 \\
\hline
\end{tabular}

Note: Respondents were asked to provide an assessment with a scale of $0-100$, where 0 means very corrupt and 100 means very clean.

Source: Transparency International (2015)

lowest corruption perception index score are Banjarmasin with 0 points, Makassar City with 2 points, and Kota Padang with 2 points. The potential corruption score of 2015 shows an increase.

Through time-to-moment comparison, corruption perception scores are currently increasing compared to the 2014 period. This increase in scores, indicates the appreciation of respondents to government efforts in eradicating corruption in the regions. Respondents also projected a potential corruption score increase in 2016. This indicates that respondents have optimism towards improved good governance and independence from corruption in the region.

\section{Perceptions of Bribe Potential}

Based on the prevalence of bribery, the city that has the highest prevalence of bribery is Pontianak City, Padang City, Banjarmasin City, and Manado City. Meanwhile, cities with low bribery prevalence are Pekanbaru City, Makassar City, and Semarang City.

Based on the average of bribery allocation, the highest percentage of bribe is Banjarmasin equal to $21 \%$ of total production cost, Manado with bribery equal to $15 \%$ from total production cost, and Bandung with 12 bribe average \% of total production. Meanwhile, the city with the lowest percentage of bribe cost is Surabaya with $1 \%$ of total production cost, Pontianak city $1 \%$ of total production cost, and Padang city $3 \%$ of total production cost.
Bribe risk based on the field of business is an assessment of the risk of bribery occurrences categorized by the type of business field actively engaged in the city where the survey is conducted. The types of bribes identified in the surveys are bribes, gratuities, lubricant money, political donations, and inter-private bribery.

The field of business that has the highest prevalence of bribery by respondents is the business in the construction and mining sectors, and the next is forestry and oil and gas. Meanwhile, the sector with low potential for bribery by respondents is agriculture sector, transportation sector, and hotel and restaurant sector.

\section{Perceptions of Business Integrity}

In a survey, business integrity is calculated based on the amount of business competition distorted by the practice of bribery. Cities with the highest bribe distorted business competition practices have poor business integrity, while cities with the lowest distorted business competition practices have low business integrity.

Cities with bad business integrity marked by the highest percentage of bribery distorted business competition are Medan with $47 \%$, Pekanbaru with 26\%, and Manado with 20\%, and Padang with $20 \%$. Meanwhile, the city with the lowest bribery distorted business competition is Makassar as much as $7 \%$, Bandung as much as $8 \%$, and Semarang as much as $10 \%$. 
Figure 2. Bribe, Prevalence, and Number of Distorted Bribe Competition

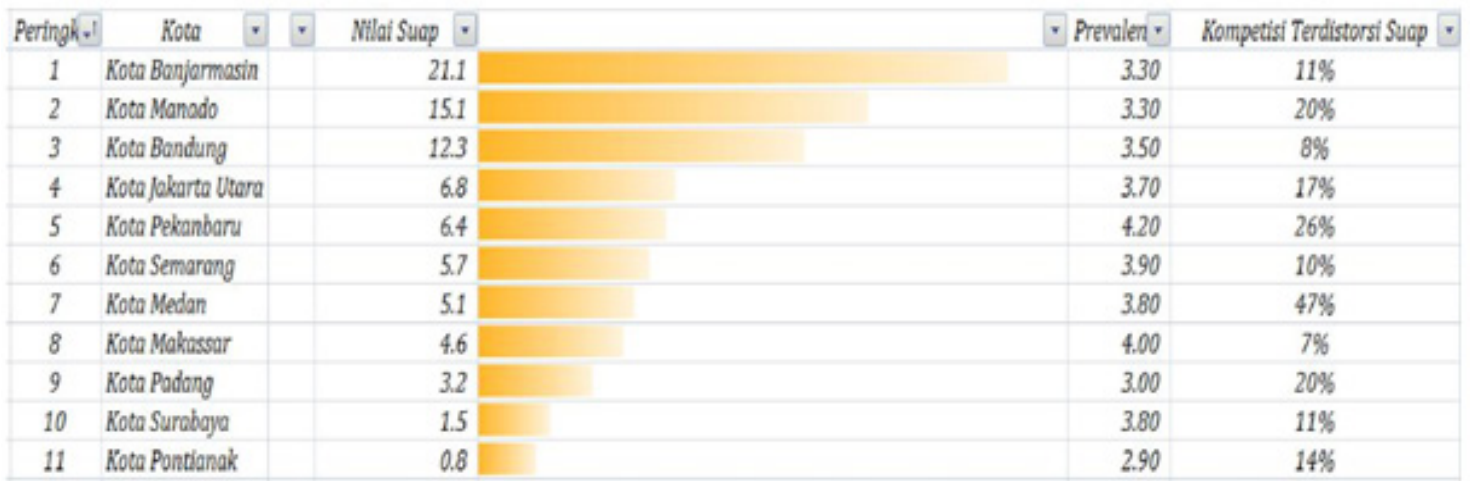

Notes:

1). The value of a bribe is a number in percentage form.

2). The Bribe Prevalence is calculated by means of respondents being asked to provide an assessment on a scale of $0-5$, where 0 means bribery is very common and 5 means very unusual.

3). Bribe distorted competitions represent numbers in percentages that describe the amount of business competition distorted by bribery practices perpetrated by business competitors.

Source: Transparency International, 2015

The business sector that has the risk of bribery distorted business competition is the banking sector as much as $69 \%$, the industrial sector as much as $56 \%$, and the trade sector as much as $55 \%$. In the meantime, sectors that have risk of business competition are distorted by bribery of respondents from the mining sector by $6 \%$, forestry sector by $7 \%$, and agricultural sector by $8 \%$.

Most of the respondents still have a commitment to fight corruption. This is characterized by their willingness to increase the role of the private sector in combating corruption. Total of 7 out of 10 respondents claimed to have responsibility and participate in the eradication of corruption. In addition, respondents also identified the necessary preconditions for the business sector to strengthen the company's integrity system. These preconditions are the joint action against corruption, the Anti-Corruption Audit Program, the Certification of Business Partners, the Implementation of AntiCorruption Policies, and the AntiCorruption Standard for the Company.

\section{Public Integrity}

Based on the assessment of bribery incidents, it can be seen that:

The central government with the highest risk of public integrity violation is the Police Department with 48 incidents, the Ministry of Trade with 37 incidents, and the Ministry of Manpower Work with 36 events. Meanwhile, central agencies with the lowest risk of bribery incidents are the Attorney General's Office with 6 incidents, Ministry of Transportation with 11 incidents, and ESDM Ministry with 13 incidents.

The greatest probability of bribery in central institutions is the Attorney General's Office with $43 \%$ probability of bribe, Ministry of Agrarian/BPN with $42 \%$ probability of bribery, and Ministry of Public Works and Menpera with a probability of $30 \%$. Meanwhile, central agencies with the lowest probability of bribery are the trade ministry with a probability of $26 \%$, the ministry of industry, the Ministry of Finance, BKPM, and the Ministry of Manpower. 
Figure 3. Local Integrity System (Expectations, Roles of Capacity and Governance)

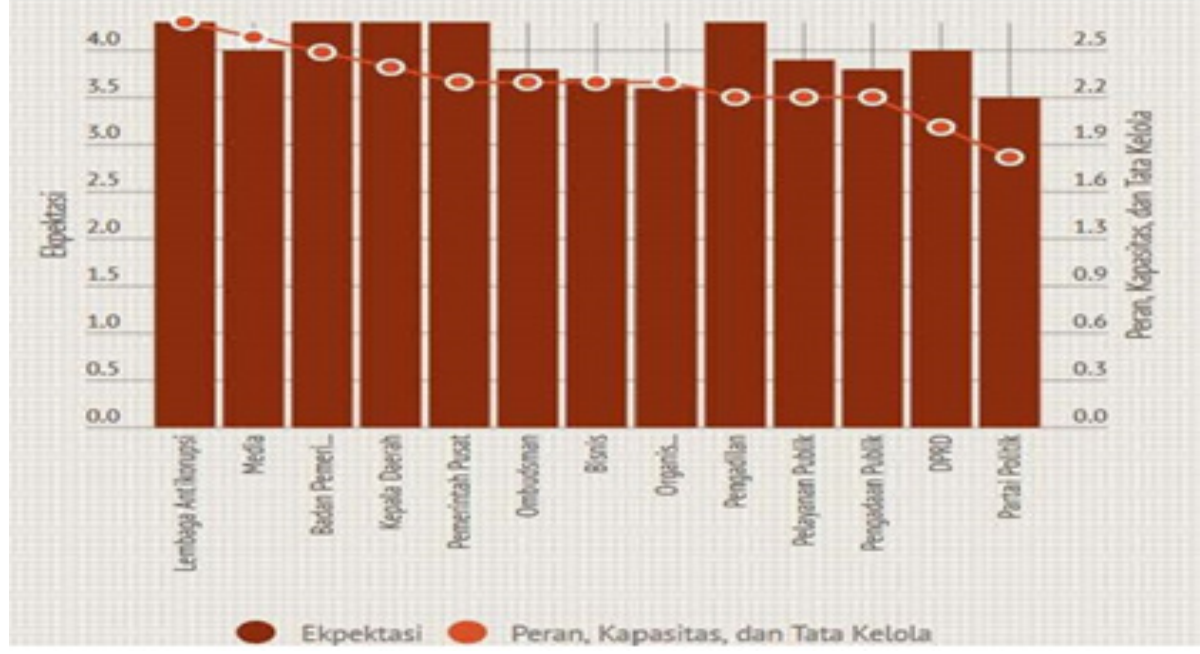

Source: Transparency International, 2015

The highest vertical service agencies with the highest bribe risk are the Provincial Tax Office with the number of 83 incidents, the Regional Police with 81 incidents, and the National Land Agency with 32 incidents. Meanwhile, the vertical service agency that has the lowest Bribe Risk is Ditjen of State Property Management with 6 incidents, Ditjen Treasury with 9 incidents and High Court with 10 incidents.

Vertical service institutions that having bribery capability are High Court with bribe probability of $43 \%$, Regional Police with $43 \%$ probability of bribery, and Provincial Land Agency with 35\% probability of bribery. Meanwhile, the vertical agency with the lowest bribery probability is the Provincial State Property Management Director with a $22 \%$ probability of bribe, the Provincial Directorate General of Taxes with $17 \%$ probability of bribe and the university with $13 \%$ bribe probability.

Provincial service agencies with the highest Bribe Risk are the Regional Police Department with 97 incidents of Trade Service amounting to 97 incidents, and Industry Agency with 71 incidents. Meanwhile, the provincial service agencies with the lowest Bribe Risk are Mining and Energy Agency with 6 incidents, Public Works Agency with 10 incidents, and the Regional Investment Coordinating Board with 25 incidents.
Provincial service agencies with bribery probabilities are Police with $42 \%$ bribe probability, District Revenue and Revenue Office with a bribe probability of $27 \%$, and the Trade Service with a bribe probability of $28 \%$. Meanwhile, the vertical agency with the lowest bribery probability is the Environment Agency with a 21\% bribery probability, the Regional Capitalization Coordinating Board with a $21 \%$ bribery probability and the Mining and Energy Agency with a $17 \%$ bribe probability.

The municipal service agency that has the highest Bribe Risk is the Integrated Licensing Service Agency with 136 cases of the Trade Service with 169 events, and the Department of Industry with 121 incidents. Meanwhile, the municipal service agencies that have the lowest Bribe Risk are Mining and Energy Agency with 10 incidents, Public Works Department with 16 cases, and Transportation Department with 26 incidents.

A municipal service agency with a bribery probability is a police force with a probability of bribe of $38 \%$, Regional Revenue and Revenue Service with a 34\% probability of bribe, and a Trade Service with a bribe probability of $28 \%$. Meanwhile, urban agencies with the lowest bribery probabilities are the Cooperative and Small and Medium-sized Enterprises with $20 \%$ probability of bribe, the Manpower 
Office with $21 \%$ bribe probability and the Mining and Energy Agency with a 22\% bribe probability.

The state-owned enterprise service agency that has the highest risk of bribery is the number of 125 events, Mandiri with the number of incidents 71, and BPJS with 93 incidents. Meanwhile, the State Agency for State-Owned Enterprises with risk is the Indonesian Railway with 8 incidents, Jasa Marga with 10 incidents, and PELNI with 6 incidents.

State-owned Enterprise Services agency with bribery probability is BRI with $72 \%$ probability of bribery, BTN service with $28 \%$ probability of bribe, and BPJS with bribe probability of $44 \%$. Meanwhile, the city agency with the lowest bribery probability is the Regional Bank with a bribe probability of $13 \%$, the PDAM with a bribe probability of $8 \%$ and PELNI with a bribe probability of $1 \%$.

\section{Local Integrity System}

The pillars of the local integrity system that are judged, consist of Regional Head, DPRD, Political Parties, Public Service, Public Procurement, Courts, Supreme Audit Board, Ombudsman, Media, Civil Society Organizations, Business
Anti-Corruption Institutions, Central government. Media and Civil Society Organizations in the regions have roles, capacities, and governance that exceed respondents' expectations. Meanwhile, the must largest repair is owned by the courts, DPRD, and Political Parties.

In terms of expectations, the majority of respondents have high expectations for heads of regions and thecentral government in an effort to mitigate corruption in the regions. The combination of both, the authority possessed by the regions and the central government provides a great hope for the eradication of corruption in the regions. From the aspect of ability, role, and governance of local integrity system, the majority of respondents have a high appraisal of anti-corruption and media agencies. The combination of these two pillars opens up opportunities for the disclosure of corruption cases through investigative journalism work, while anticorruption agencies have opportunities through the prosecution and prevention of corrupt behavior in the regions.

Among the surveyed cities, in relatively Surabaya, Semarang, and Manado occupied the top of the city with

Table 2. Corruption Perception, Perception Bribery, Business Integrity, Public Integrity, Local Integration System and Local Economic Growth in 11 Cities by Rank

\begin{tabular}{cccccc}
\hline No & City & $\begin{array}{c}\text { Corruption } \\
\text { Perception }\end{array}$ & $\begin{array}{c}\text { Business } \\
\text { Integrity }\end{array}$ & $\begin{array}{c}\text { Public } \\
\text { Integrity }\end{array}$ & $\begin{array}{c}\text { Local Integration } \\
\text { System }\end{array}$ \\
\hline 1 & Banjarmasin & 1 & 5 & 6 & 5 \\
2 & Surabaya & 2 & 4 & 9 & 1 \\
3 & Semarang & 3 & 3 & 2 & 3 \\
4 & Pontianak & 4 & 6 & 1 & 6 \\
5 & Medan & 5 & 11 & 10 & 11 \\
6 & Jakarta Utara & 6 & 7 & 7 & 8 \\
7 & Manado & 7 & 8,5 & 8 & 2 \\
8 & Padang & 8 & 8,5 & 4 & 7 \\
9 & Makassar & 9 & 1 & 5 & 4 \\
10 & Pekanbaru & 10 & 10 & 11 & 9 \\
11 & Bandung & 11 & 2 & 3 & 10 \\
\hline
\end{tabular}

Note: The lowest rating is the best.

Source: the result of the data 
a good local integrity system. Meanwhile, Pekanbaru, Bandung, and Medan ranks the lowest city with low local integrity system.

The Relationship of Perceptions of Corruption Potential, Business Integrity, Public Integrity, and Integrity Systems

The following table of data accumulation is a rank table of potential corruption perceptions, business integrity perceptions, public integrity perceptions and local integrity systems. These data are used to see the inter-relationship between these variables.

The test results of the relationship between variables using Rank Spearman, gives the following output (Table 5).

From the results of the above correlation test, shows that there are several relationships between variables.

There is a relationship between the perception of potential corruption with the local integration system. If the lower gap between expectations and role-capacitygovernance, the stronger the local integrity system, then there is a better perception of corruption eradication. Vice versa, the higher gap between expectations and rolecapacity-governance, the weaker the local integrity system.

There is a relationship between the local integration system and the perception of business integrity. Expectations and rolecapacity-better governance will strengthen firm commitments with business implementation with integrity.

There is a relationship between perceptions of business integrity and public integrity. The business integrity commitment of the entrepreneur will be established if there is confidence in the suitability of service procedures and the implementation of good public services without the need for bribery.

\section{CONCLUSION}

In the eradication of corruption that has been systemic, should be aware of the need for a systemic approach too. It is necessary to analyze local systematic mapping to find out which pillars contribute the most to role, capacity and governance, in efforts to eradicate corruption. With good local integration system, entrepreneurs will be able to reduce business risk with implementation of busines integrity. With good integrity from these entrepreneurs, it will encourage the improvement of public integrity. Conversely, the higher incidents of bribery by employers, the public's integrity will get worse. It appears that the eradication of corruption can not be initiated from public integrity but must begin with a clean system improvement. These findings suggest public integrity has an indirect relationship with potential corruption. Areas with poor public integrity will have high potential for corruption.

\section{REFERENCES}

ACFE Indonesia Chapter \#111. (2016). Survai Fraud Indonesia, Association of Certified fraud Examiners.

Badan Pusat Statistik (Central Bureau of Statistics)

Badan Pusat Statistik (2012). Survei Perilaku Anti Korupsi (SPAK) 2012, Badan Pusat Statisik, JakartaIndonesia.

Guy J. Pauker (1980), Indonesia 1979: The Record of Three Decades (Asia Survay Vol XX No. 2)

Hamzah, Andi (1991), Korupsi di Indonesia: Masalah dan Pemecahannya Jakarta: PT Gramedia.

Hamzah, Andi (1991), Pemberantasan Korupsi Melalui Hukum Pidana Nasional dan Internasional, Jakarta: PT Raja Grafindo Persada

Kennedy, Posma Sariguna Johnson \& Siregar, Santi Lina. (2017). Para Pelaku Fraud di Indonesia menurut Survei Fraud Indonesia, Buletin Ekonomi FEUKI ISSN-14103842 Vol.21 No.2 September 2017, p.50-58.

KPK (2006), Tambahan Penghasilan bagi Pegawai Negeri Sipil Daerah Jakarta: KPK 
232 Posma S. J Kennedy \& Santi Lina, The Relation of Corruption Potential Perception

Pope, Jaremy, (2003) Strategi Memberantas Korupsi: Elemen Sistem Integritas Nasional, Jakarta: Yayasan Obormas Indonesia

Siregar, Santi Lina. (2017). Literature Review: Perilaku Korupsi dan Penyebabnya, Fundamental Management Journal ISSN: 2540-9816 (print) 2540-9220 (online) Volume:2 No.1 April, p.47-56.
Sulistyantoro, HT. (2004), Etika Kristen dalam Menyikapi Korupsi, Kompas, Senin, 2 Agustus 2004

Transparency International. Corruption Perception Index.

Transparency International Indonesia. (2015). Survei Persepsi Korupsi 2015, Danida. 